\title{
URGENSI PERLINDUNGAN HUKUM KONSUMEN DAN PENYELESAIAN SENGKETA E-COMMERCE DI ERA MASYARAKAT EKONOMI ASEAN
}

\author{
(The Urgency of Consumer Law Protection and the E-Commerce Dispute Resolution \\ in the Era of ASEAN Economic Community)
}

\author{
Arfian Setiantoro; Fayreizha Destika Putri; Anisah Novitarani; dan Rinitami Njatrijani \\ Fakultas Hukum Universitas Diponegoro \\ JI. Imam Bardjo, S.H. No.1-3 Kampus Undip Pleburan Semarang \\ Email: arfian.elnino@gmail.com; fayreizhadp@gmail.com; anisanovitarani@gmail.com; njatrijani@yahoo.com
}

Naskah diterima: 19 Februari 2018; revisi: 5 April 2018; disetujui: 12 April 2018

\begin{abstract}
Abstrak
Di era globalisasi, Masyarakat Ekonomi ASEAN (MEA) mendorong perkembangan e-commerce yang belum sepenuhnya terlindungi dengan UU No. 8 Tahun 1999 tentang Perlindungan Konsumen (UUPK). Berkaitan dengan masalah tersebut, tulisan ini membahas mengenai urgensi perlindungan konsumen dan alternatif penyelesaian sengketa terhadap transaksi e-commerce di Era Masyarakat Ekonomi ASEAN. Metode pendekatan yang digunakan dalam penelitian ini adalah pendekatan yuridis normatif dan bersifat deskriptif analitis. Hasil penelitian menunjukkan bahwa perangkat hukum di Indonesia saat ini belum mengatur secara lengkap perlindungan hukum terhadap konsumen dalam transaksi e-commerce. Mekanisme penyelesaian sengketa yang tersedia adalah baik melalui peradilan maupun di luar peradilan. Lembaga nonlitigasi seperti BPSK, ODR maupun ACCP diharapkan dapat lebih melindungi konsumen untuk menemukan win-win solution. Di masa mendatang, perlindungan konsumen haruslah bersifat preventif dan diperlukan sinergisitas antar peraturan yang dibuat pemerintah agar terdapat perlindungan hukum yang semakin lengkap bagi konsumen.

Kata Kunci: konsumen cerdas, e-commerce, penyelesaian sengketa, perlindungan konsumen, Masyarakat Ekonomi Asean (MEA)

Abstract

In the globalization era, ASEAN Economy Community (MEA) has accelerated the development of e-commerce which has not been fully covered by Law Number 8 Year 1999 on Consumer Protection. Therefore, this paper examines the urgency of consumer protection and alternative dispute for e-commerce in the era of MEA. This study used normative juridical approach with analytical descriptive study. The result of the research shows currently Indonesia legal framework has not provided sufficient legal protection for consumers in e-commerce transaction. Available dispute resolutions mechanism are through the court or outside the court. Non-litigation institutions such as Consumer Dispute Settlement Bodies, ODR or ACCP are expected to protect and help consumers find win-win solution. In the future, consumer protection should be preventive and synchronization among regulations is needed to provide a comprehensive legal protection for the consumers.
\end{abstract}

Keywords: smart consumer, e-commerce, dispute resolution, consumer protection, ASEAN Economic Community (MEA). 


\section{A. Pendahuluan}

Kemajuan di bidang ilmu pengetahuan membuat teknologi menjadi selalu baru, tanpa terkecuali bidang telekomunikasi khususnya media internet. Adanya perkembangan tersebut membuat ruang gerak transaksi barang dan/atau jasa dapat melintasi batas-batas wilayah suatu negara dengan bebas. Kondisi sedemikian rupa mendukung efek pertumbuhan ekonomi yang lebih luas di dunia. Indonesia juga merasakan efek tersebut sehingga perkembangan arus barang dan/jasa menjadi mudah didapatkan terkhususnya yang diuntungkan adalah konsumen.

Di era globalisasi, ketika batas-batas suatu negara akan menjadi kabur, di satu pihak keterkaitan antara ekonomi nasional dengan perekonomian internasional akan semakin erat. ${ }^{1}$ Di lain pihak, kondisi globalisasi saat ini dapat mengakibatkan kedudukan pelaku usaha dan konsumen menjadi tidak seimbang. Konsumen dapat menjadi obyek aktivitas bisnis dari pelaku usaha melalui iklan, promosi, cara penjualan, serta penerapan perjanjian-perjanjian standar yang merugikan konsumen.

Hadirnya MEA (Masyarakat Ekonomi ASEAN) merupakan suatu integrasi atas negara-negara di kawasan Asia Tenggara khususnya, yang bertujuan untuk memperkecil kesenjangan antara negara-negara ASEAN dalam hal pertumbuhan perekonomian. Hal itu membuat meningkatnya persaingan antar negaranegara ASEAN dalam hal produk maupun jasa. Untuk menjamin terciptanya tingkat persaingan yang tinggi dan adil, MEA membentuk sebuah kebijakan berupa perlindungan konsumen yang juga menjamin adanya arus informasi yang akurat di pasar barang dan jasa.

Dengan pemahaman bahwa semua masyarakat adalah konsumen, maka melindungi konsumen berarti juga melindungi seluruh masyarakat. Sesuai dengan amanat Alinea ke-IV Pembukaan Undang-Undang Dasar Negara Republik Indonesia tahun 1945, maka perlindungan konsumen menjadi penting. Lagi pula, jika disadari bahwa konsumen atau masyarakat adalah pelaksana pembangunan yang sekaligus juga sumber pemupukkan modal bagi pembangunan, maka untuk kelangsungan pembangunan nasional mutlak diperlukan perlindungan kepada konsumen itu. ${ }^{2}$ Meski demikian, pada kenyataannya pendidikan bagi konsumen masih tergolong minim dan kesadaran para konsumen akan hak-hak dan kewajibannya masih rendah. Untuk menjamin suatu penyelenggaraan Perlindungan Konsumen, maka pemerintah menetapkan Undang-Undang Nomor 8 Tahun 1999 tentang Perlindungan Konsumen (UUPK) yang memaksa pelaku usaha untuk menaatinya, disertai dengan sanksi yang tegas bagi pelanggarnya.

Penyelesaian perselisihan terhadap sengketa yang dihadapi masyarakat termasuk dalam hal sengketa konsumen, dapat diselesaikan melalui jalur litigasi (melalui pengadilan) dan jalur non-litigasi (tidak melalui pengadilan). Selain itu, menurut Peraturan Mahkamah Agung No. 2/2015, konsumen kini memiliki beberapa alternatif dalam penyelesaian sengketanya. Penyelesaian gugatantersebut menjadikan angin segar dalam alternatif penyelesaian sengketa yang biasanya hanya bisa diselesaikan dalam

$1 \quad$ Francis Fukuyama, The End of History and The Last of Man, Kemenangan Kapitalisme dan Demokrasi Liberal, Terjemahan oleh: Amrullah, (Yogyakarta:Qalam,2004), hlm. 4.

2 Ibid., hlm. 3. 
ranah litigasi. Untuk itu, muncullah lembaga non-litigasi misal melalui Badan Penyelesaian Sengketa Konsumen (BPSK) maupun lembaga/ forum lain yang dapat menyelesaikan sengketa tersebut.

Tantangan lain mengenai perlindungan hukum terhadap konsumen adalah perkembangan e-commerce (transaksi elektronik) yang terus berkembang cepat seiring berkembangnya teknologi telekomunikasi yang maju, sehingga peluang terjadinya sengketa akan menjadi sangat serius. Di sisi lain, perkembangan MEA sejak tahun 2015 semakin menggeliat di tataran ASEAN. Jika sengketa e-commerce terjadi antar negara diperlukan kajian yang lebih mendalam dan restrukturisasi aturan antar negara untuk menyelesaikan sengketa tersebut. UndangUndang Nomor 30 Tahun 1999 yang mengatur arbitrase secara konvensional, saat ini masih bisa digunakan sebagai alternatif penyelesaian sengketa, namun aturan di dalamnya masih banyak kelemahan karena tidak mengatur secara rinci masalah penyelesaian sengketa e-commerce. Berdasarkan uraian latar belakang di atas, tulisan ini bertujuan membahas mengenai perlindungan konsumen dan alternatif penyelesaian sengketa dalam transaksi e-commerce di era Masyarakat Ekonomi ASEAN.

\section{B. Metode Penelitian}

Metode pendekatan yang digunakan dalam penelitian ini adalah pendekatan yuridis normatif. Pendekatan yuridis adalah suatu pendekatan yang mengacu pada hukum dan peraturan perundang-undangan yang berlaku ${ }^{3}$, sedangkan pendekatan normatif adalah pendekatan yang dilakukan dengan cara meneliti bahan pustaka atau data sekunder terhadap asas-asas hukum serta studi kasus yang dengan kata lain sering disebut sebagai penelitian hukum kepustakaan. ${ }^{4}$ Metode pengumpulan data yang digunakan pada penelitian ini adalah metode penelitian kepustakaan. Data kepustakaan yang diperoleh melalui penelitian kepustakaan yang bersumber dari peraturan perundangundangan, buku-buku, dokumen resmi, publikasi dan hasil penelitian. ${ }^{5}$ Berdasarkan sifat penelitian ini yang menggunakan metode penelitian bersifat deskriptif analitis, analisis data yang dipergunakan adalah pendekatan kualitatif terhadap data primer dan data sekunder. Deskriptif tersebut, meliputi isi dan struktur hukum positif, yaitu suatu kegiatan yang dilakukan oleh penulis untuk menentukan isi atau makna aturan hukum yang dijadikan rujukan dalam menyelesaikan permasalahan hukum yang menjadi objek kajian. ${ }^{6}$

\section{Pembahasan}

\section{Perlindungan Hukum Konsumen terhadap Transaksi E-Commerce di eEa Masyarakat Ekonomi ASEAN}

Perkembangan pasar bebas Masyarakat Ekonomi Asean (MEA) yang semakin pesat membuat cara berniaga berubah menuju electronic commerce (e-commerce). Di era modern dan digital saat ini, aktifitas perdagangan e-commerce telah menjadi senjata utama yang dapat memudahkan transaksi perdagangan. E-commerce adalah proses pembelian,

Roni Hanitjo Soemitro, Metodologi Penelitian Hukum dan Jurimetri, (Jakarta: Ghalia Indonesia,1982), hlm. 20.

4 Soerjono Soekanto dan Sri Mamudji, Penelitian Hukum Normatif Suatu Tinjauan Singkat, (Jakarta: PT. Raja Grafindo Persada, 2004), hlm. 13.

Zainuddin Ali, Metode Penelitian Hukum, (Jakarta: Sinar Grafika,2010), hlm. 107.

6 Ibid. 
penjualan, transfer, atau pertukaran produk, jasa dan informasi melalui jaringan komputer termasuk internet. ${ }^{7}$ Menurut M. Pattinson "There are several features, which distinguish electronic commerce from business conducted by traditional means. In particular: electronic commerce establishes a global market-place, where traditional geographic boundaries are not ignored, they are quite simply irrelevant..."
Laporan Digital In 2017 Growth Overview menyatakan secara statistik bahwa masyarakat Indonesia menghabiskan waktu sekitar 3 jam 16 menit per-hari untuk media sosial. ${ }^{9}$ Data "Time on Site" dari SimilarWeb yang menghitung waktu kunjungan dari 30 toko online yang beroperasi di Indonesia dan telah dibuat dari Maret 2017 lalu menunjukkan rata-rata konsumen Indonesia menghabiskan

Gambar 1. Grafik Perkembangan Nilai Transaksi E-Commerce Indonesia

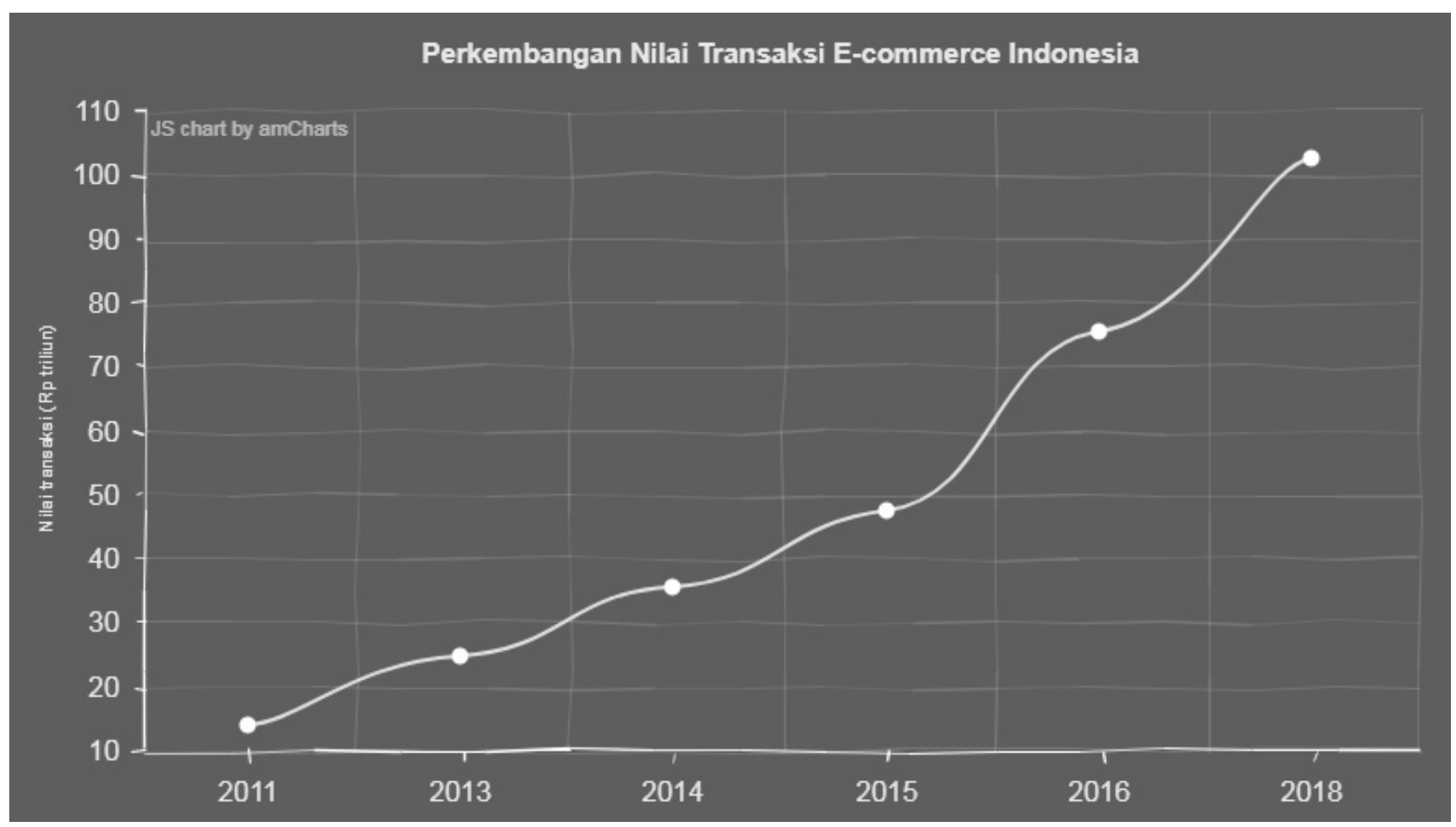

Sumber: (https://kumparan.com/@kumparanbisnis/yustinus-prastowo-sistem-terintegrasi-jadi-kunci-regulasi-e-commerce)

\footnotetext{
Philip F. E. Adipraja, Sri A.K. Dewi, Lia Farokhah, Analisis Efektifitas dan Keamanan E-Commerce di Indonesia dalam Menghadapi MEA, Sekolah Tinggi Manajeman Informatika \& Komputer Perguruan Tinggi ASIA, Malang, hlm. 113, https://www.researchgate.net/profile/Philip_Adipraja/publication/303699038_ANALISIS_EFEKTIFITAS_DAN_ KEAMANAN_ECOMMERCE_DI_INDONESIA_DALAM_MENGHADAPI_MEA/links/5982c8b8458515a60df81139/ ANALISIS-EFEKTIFITAS-DAN-KEAMANAN-ECOMMERCE-DI-INDONESIA-DALAM-MENGHADAPI-MEA.pdf (diakses pada 11 Februari 2018)

8 Mansur, D. M. A., dan E. Gultom, Cyber Law: Aspek Hukum Teknologi Informasi, (Bandung: Refika Aditama, 2005), hlm. 145, Artikel dalam Jurnal online: Urgensi Regulasi Komprehensif E-Commerce di Indonesia dalam Menghadapi Masyarakat Ekonomi ASEAN (MEA), http://ojs.uma.ac.id/index.php/mercatoria/article/view/648, (diakses pada 11 Februari 2018).

9 Risky Maulana, Tren Perilaku Konsumen Belanja Online Indonesia Tahun 2018 Menurut iPrice, https://id.techinasia. com/tren-perilaku-konsumen-online-indonesia-menurut-iprice (diakses pada 13 Februari 2018).
} 
waktu sebanyak 4 menit 9 detik dalam sekali kunjungan ke situs belanja online. Riset Nielsen tahun 2014 menunjukkan 80\% perilaku konsumen Indonesia masih menggunakan situs toko online untuk melihat review produk yang diinginkan sebelum membelinya secara offline. Hal tersebut dikarenakan masih banyak konsumen Indonesia yang belum percaya terhadap sistem transaksi online yang bahkan terkadang ada toko online yang meminta data informasi kartu kredit konsumen. ${ }^{10}$ Indonesia adalah negara berpenduduk terbesar ke empat di dunia dengan jumlah penduduk 262 juta jiwa dan ditopang oleh penduduk berpendapatan menengah (middle-income). Hal ini menjadikan Indonesia sebagai pasar bagi produk negaranegara asing di era MEA. Hal itu semakin menjadi-jadi, karena (biasanya) konsumen akan lebih percaya diri (prestige) saat mengenakan barang asing. ${ }^{11}$

Berdasarkan data terakhir Bank Indonesia (BI) pada tahun 2016, transaksi e-commerce mencapai Rp 75 triliun per tahun. Nilai itu termasuk transaksi e-commerce non market place. Jika diasumsikan selama 10 tahun terakhir rata-rata pertumbuhan nilai transaksi e-commerce mencapai 17\%, maka tahun 2018 nilai transaksi e-commerce diperkirakan sampai Rp 102 triliun. ${ }^{12}$ Perkembangan e-commerce di
Indonesia seperti sekarang ini memang sangat signifikan.

Beberapa permasalahan yang timbul yang berkenaan dengan hak-hak konsumen dalam transaksi e-commerce, antara lain: ${ }^{13}$

a. Konsumen tidak dapat langsung mengidentifikasi, melihat, atau menyentuh barang yang akan dipesan;

b. Ketidakjelasan informasi tentang produk yang ditawarkan dan/atau tidak adanya kepastian apakah konsumen telah memperoleh berbagai informasi yang layak diketahui, atau yang seharusnya dibutuhkan untuk mengambil suatu keputusan dalam bertransaksi;

c. Tidak jelasnya status subjek hukum, dari pelaku usaha;

d. Tidak ada jaminan keamanan bertransaksi dan privasi serta penjelasan terhadap risiko-risiko yang berkenaan dengan sistem yang digunakan, khususnya dalam hal pembayaran secara elektronik baik dengan menggunakan credit card maupun electronic cash;

e. Pembebanan risiko yang tidak berimbang, karena umumnya terhadap jual beli di internet, pembayaran telah lunas dilakukan di muka oleh konsumen, sedangkan barang belum tentu diterima atau akan menyusul

10 Ibid.

11 Abdul Manap Pulungan, Indonesia dan MEA: Bertarung dengan Tangan Kosong,https://www.cnnindonesia.com/ ekonomi/20151231160041-79-101461/indonesia-dan-mea-bertarung-dengan-tangan-kosong (diakses pada 13 Februari 2018)

12 Adinda Ade Mustami, Sumbangan Transaksi E-Commerce ke PDB Diperkirakan Hanya 0,75\%, http://nasional. kontan.co.id/news/sumbangan-transaksi-e-commerce-ke-pdb-diperkirakan-hanya-075 (diakses pada 15 Februari 2018)

13 Farizal F. Kamal, Cyber Business, cet. 3. (Jakarta: Elex Media Komputindo, 1999)..hlm. 81, Artikel dalam Jurnal Online Tetanoe Bernada, Upaya Perlindungan Hukum Pada Konsumen Dalam Transaksi E-commerce Untuk Mendukung Pertumbuhan Ekonomi Digital Di Indonesia, https://www.researchgate.net/publication/317562107_ UPAYA_PERLINDUNGAN_HUKUM_PADA_KONSUMEN_DALAM_TRANSAKSI_ECOMMERCE_UNTUK_ MENDUKUNG_PERTUMBUHAN_EKONOMI_DIGITAL_DI_INDONESIA_LEGAL_PROTECTION_FOR_ECOMMERCE_ TRANSACTION'S_CONSUMERS_TO_SUPPORT_THE_DIGITAL (diakses pada 01 April 2018). 
kemudian, karena jaminan yang ada adalah jaminan pengiriman barang bukan penerimaan barang;

f. Transaksi yang bersifat lintas batas negara borderless, menimbulkan pertanyaan mengenai yurisdiksi hukum negara mana yang sepatutnya diberlakukan.

\section{Berdasarkan data Yayasan Lembaga} Konsumen Indonesia (YLKI), sepanjang tahun 2017, YLKI telah menerima 642 aduan di luar pengaduan biro perjalanan umrah. Dari 642 aduan tersebut, aduan yang berasal dari belanja online mendominasi dengan jumlah 101 aduan. Sementara dari toko online yang paling sering diadukan, urutan pertama adalah Lazada dengan 18 aduan, Akulaku dengan 14 aduan, Tokopedia dengan 11 aduan, Bukalapak dengan 9 aduan, Shopee dengan 7 aduan, Blibli.com dengan 5 aduan, JD.ID dengan 4 aduan, dan Elevenia dengan 3 aduan. Adapun permasalahan yang sering diadukan kepada YLKI adalah pesanan barang yang belum sampai, cacat produk, sulitnya proses pengembalian barang, hingga proses refund atau pengembalian uang. ${ }^{14}$

Selain persoalan perlindungan konsumen, salah satu persoalan yang juga timbul terkait transaksi e-commerce saat ini adalah terkait dengan layanan keuangan, yaitu penggunaan e-money. E-money sebenarnya sudah hadir sejak tahun 2007 yang diatur dalam Peraturan Bank Indonesia No. 11/12/PBI/2009 tentang Uang Elektronik. E-money merupakan alat pembayaran dengan ketentuan bahwa nilai uang yang disimpan secara elektronik didasarkan pada nilai uang yang telah disetorkan terlebih dahulu oleh pemilik kartu elektronik dan dapat digunakan sebagai alat bayar untuk sejumlah produk atau layanan nilai elektronik yang lebih spesifik. $^{15}$

Terhadap

penggunaan

e-money,

pembebanan biaya untuk isi ulang (top up) uang elektronik (e-money) kepada konsumen dipersoalkan masyarakat. Kebijakan Peraturan Bank Indonesia (PBI) Nomor 19/8/PBI/2017 tentang Gerbang Pembayaran nasional dinilai kurang tepat. PBI tersebut mengatur dua cara pengisian saldo uang elektronik yakni pertama dengan cara off us atau lintas kanal pembayaran dikenakan Rp. 1.500,- dan kedua cara on us atau satu kanal, di mana pada pengisian ulang sebesar Rp. 200.000,- tidak kena biaya (gratis) sedangkan transaksi di atas nilai tersebut dikenakan biaya maksimal Rp. 750,-.

Kebijakan Bank Indonesia (BI) ini tidak sejalan dengan tujuan Gerakan Nasional Non Tunai dan jelas tidak adil bagi konsumen. Substansi tersebut cenderung mengedepankan kepentingan dunia usaha perbankan. Kebijakan $\mathrm{BI}$ menyebabkan ketidakadilan bagi sebagian konsumen, khususnya masyarakat yang mengisi ulang di atas Rp. 200.000,- pada bank atau lembaga penerbit atau mengisi ulang pada merchant. Konsumen seharusnya mendapat insentif bukan disinsentif dalam pelaksanaan program cashless society. ${ }^{16}$

14 Pramdia Arhando Julianto, YLKI: Meski Dirugikan, Konsumen Indonesia Takut Melapor, https://ekonomi.kompas. com/read/2018/01/19/153100426/ylki--meski-dirugikan-konsumen-indonesia-takut-melapor (diakses pada 01 April 2018).

15 Admin PilihKartu.com, E-Wallet Bentuk Lain dari E-Money yang Sebaiknya Kamu Tahu, https://pilihkartu.com/ tips-kartu-kredit/ewallet-bentuk-lain-dari-emoney-yang-sebaiknya-kamu-tahu (diakses pada 01 April 2018).

16 Feby Novalius, Top Up E-Money Kena Biaya, Kepala BPJT: Harusnya Tidak, https://economy.okezone.com/ $\mathrm{read} / 2017 / 09 / 26 / 320 / 1783052 /$ top-up-e-money-kena-biaya-kepala-bpjt-harusnya-tidak (diakses pada 01 April 2018). 
Undang-Undang Perlindungan Konsumen sebenarnya telah mengatur hak dan kewajiban pelaku usaha serta larangan-larangan yang bertujuan untuk memberi perlindungan terhadap konsumen. Selain itu UUPK juga mengatur mengenai hak dan kewajiban konsumen. Beberapa hak konsumen yang diatur dalam Pasal 4 UUPK adalah:

a. Hak atas kenyamanan, keamanan, dan keselamatan dalam mengkonsumsi barang dan/atau jasa;

b. Hak untuk memilih serta mendapatkan barang dan/atau jasa sesuai dengan nilai tukar dan kondisi serta jaminan yang dijanjikan;

c. Hak atas informasi yang benar, jelas, dan jujur;

d. Hak untuk didengar pendapat dan keluhannya;

e. Hak untuk mendapatkan advokasi, perlindungan, dan upaya penyelesaian sengketa perlindungan konsumen secara patut;

f. Hak untuk mendapat pembinaan dan pendidikan konsumen;

g. Hak untuk diperlakukan atau dilayani secara benar dan jujur serta tidak diskriminatif;

h. Hak untuk mendapatkan kompensasi, ganti rugi dan/atau penggantian, apabila barang dan/atau jasa yang diterima tidak sesuai dengan perjanjian atau tidak sebagaimana mestinya. i. Hak-hak yang diatur dalam ketentuan peraturan perundang-undangan lainnya.

Selain haknya yang sebagaimana disebutkan di atas, konsumen juga memiliki beberapa kewajiban yang diatur dalam Pasal 5, dalam hal ini supaya konsumen tidak mendapatkan kerugian karena ketidakhati-hatiannya sendiri. Kewajiban tersebut di antaranya adalah:

a. Membaca atau mengikuti petunjuk informasi dan prosedur pemakaian atau pemanfaatan barang dan/atau jasa, demi keamanan dan keselamatan;

b. Beritikad baik dalam melakukan transaksi pembelian barang dan/atau jasa;

c. Membayar sesuai dengan nilai tukar yang disepakati;

d. Mengikuti upaya penyelesaian hukum sengketa perlindungan konsumen secara patut.

Meski UUPK telah mengatur hak serta kewajiban pengusaha untuk memberikan perlindungan pada konsumen maupun hak dan kewajibankonsumen, namun padakenyataannya belum dapat sepenuhnya melindungi konsumen dalam transaksi e-commerce karena kemajuan ilmu pengetahuan dan teknologi dalam proses produksi barang dan jasa ternyata belum diikuti dengan kemajuan perangkat hukum yang ada. ${ }^{17}$ Pengaturan perlindungan hukum terhadap konsumen dalam transaksi e-commerce perlu mencakup hal-hal sebagai berikut: ${ }^{18}$

17 Mohammad Ikbal, Aspek Hukum Perlindungan Konsumen dalam Transaksi Elektronik (E-Commerce) Menghadapi Masyarakat Ekonomi ASEAN 2015, hlm. 18, https://ojs.uniska-bjm.ac.id/index.php/aldli/article/view/223 (diakses pada 11 Februari 2018).

18 Philip F. E. Adipraja, Sri A.K. Dewi, Lia Farokhah, Analisis EfektifitasdanKeamanan E-Commercedi Indonesiadalam Menghadapi MEA, (Malang:Mantri, 2007), hlm. 114,https://www.researchgate.net/profile/Philip_Adipraja/ publication/303699038_ANALISIS_EFEKTIFITAS_DAN_KEAMANAN_ECOMMERCE_DI_INDONESIA_DALAM_ MENGHADAPI_MEA/links /5982c8b8458515a60df81139/ANALISIS-EFEKTIFITAS-DAN-KEAMANAN ECOMMERCE-DI-INDONESIA-DALAM-MENGHADAPI-MEA.pdf (diakses pada 11 Februari 2018). 
a. Perlindungan hukum dari sisi pelaku usaha, pelaku usaha berkewajiban mencantumkan identitas dalam website. Adanya lembaga penjamin keabsahan toko online, di Indonesia tidak ada lembaga penjaminan keabsahan toko tersebut, sehingga dimungkinkan konsumen bertransaksi dengan toko online yang fiktif. Untuk itu, pemerintah melalui Departemen Komunikasi dan Informatika sedang mempersiapkan lembaga Certification Authority (CA) untuk menjamin keabsahan suatu toko online dalam beroperasi dengan menerbitkan sertifikat digital.

b. Perlindungan hukum dari sisi konsumen, adanya jaminan perlindungan kerahasiaan data-data pribadi konsumen, karena datadata tersebut jika tidak dijaga kerahasiaannya oleh pelaku usaha, dapat diperjual-belikan oleh pihak lain untuk kepentingan promosi.

c. Perlindungan hukum terhadap konsumen dari sisi produk, dimana pelaku usaha diwajibkan untuk memberikan informasi yang jelas dan lengkap mengenai produk yang ditawarkan, informasi produk mengenai produk harus diberikan melalui bahasa yang mudah dimengerti dan tidak menimbulkan penafsiran lain, memberikan jaminan bahwa produk yang ditawarkan aman atau nyaman untuk dikonsumsi atau dipergunakan, serta memberi jaminan bahwa produk yang ditawarkan sesuai dengan apa yang dipromosikan oleh pelaku usaha.

d. Perlindungan hukum terhadap konsumen dari sisi transaksi, tidak semua konsumen paham akan cara bertransaksi melalui media internet sehingga dalam hal ini, pelaku usaha perlu mencantumkan dengan jelas dan lengkap mengenai mekanisme transaksi serta hal-hal lain berkenaan dengan transaksi (diatur dalam Terms and Conditions). Apabila terjadi sengketa di antara para pihak yang bertransaksi, maka dokumen-dokumen kertas itulah yang akan diajukan sebagai bukti oleh masing-masing pihak untuk memperkuat posisi hukum masing-masing.

Selain UUPK, e-commerce yang menggunakan transaksi elektronik yang juga terkait erat dengan Undang-Undang No 11 Tahun 2008 tentang Informasi dan Transaksi Elektronik (ITE) dan Undang-undang Republik Indonesia No 7 Tahun 2014 tentang Perdagangan. Undang-Undang Perdagangan ini telah mengatur perdagangan sistem elektronik dengan ketentuan bahwa setiap orang atau badan usaha yang memperdagangkan barang atau jasa wajib menyediakan data dan informasi secara lengkap dan benar. Pada Undang-Undang Perdagangan tersebut, e-commerce diatur dalam Bab VIII Perdagangan Melalui Sistem Elektronik pada Pasal 65 dan 66.

Perangkat-perangkat hukum yang telah dikemukakan di atas tentu memiliki peranan penting dalam melindungi konsumen. Namun, konsumen juga perlu menjadi cerdas dan kristis agar terhindar dari kerugian. Pemerintah dalam setiap kampanyenya selalu mendorong agar konsumen di posisikan sebagai pihak yang "cerdas" dan "kritis". Namun, kenyataannya berdasarkan hasil survei Indeks Keberdayaan Konsumen (IKK) di 13 kota besar di Indonesia, IKK hanya mencapai 30,8. Angka ini turun dibandingkan dengan IKK 2015 yang sempat mencapai 34,17 dari nilai maksimal 100. IKK Indonesia jauh lebih rendah dibandingkan nilai perhitungan IKK di 29 negara Eropa pada tahun 2011 yang sudah mencapai rata-rata 51,31. Dengan nilai IKK hanya sebesar 34,17 bahwa 
keberdayaan konsumen Indonesia hanya sebatas level paham soal hak dan kewajiban, tetapi belum sepenuhnya mau memperjuangkannya. ${ }^{19}$

Agar dapat menjadi konsumen cerdas di era MEA, masyarakat dapat menerapkan beberapa hal berikut ini: ${ }^{20}$

a. Memahami UUPK

Memahami UU yang melindungi konsumen sangat perlu dilakukan terutama di era persaingan bebas MEA saat ini. UUPK menjadi pedoman kita mengambil keputusan selaku konsumen yang melakukan transaksi jual beli. Akan tetapi menurut Kementerian PPN/ Bappenas (2016) diketahui hanya 30\% saja masyarakat yang sudah mengetahui adanya UUPK, bahkan 52\% diantaranya hanya pernah mendengar saja. Untuk itu, sudah saatnya konsumen memahami UUPK yang menjadi dasar mereka untuk mendapatkan perlindungan

b. Menjalankan Hak dan Kewajiban konsumen sesuai dengan UUPK

c. Cerdas dalam memilih produk.

Pemerintah melalui Kementerian Perdagangan (Kemendag) menerapkan proteksi atau perlindungan dengan menerbitkan Peraturan Menteri

Perdagangan Nomor 72/M-DAG/
PER/9/2015 Tahun 2015 Tentang Perubahan Ketiga atas Peraturan Menteri Perdagangan Nomor 14/M-DAG/PER/3/2007 Tentang Standarisasi Jasa Bidang Perdagangan dan Pengawasan Standar Nasional Indonesia

(SNI) Wajib terhadap Barang dan Jasa yang Diperdagangkan.

d. Berani melindungi diri.

Konsumen dituntut untuk dapat melindungi diri meskipun pemerintah telah berupaya memberikan perlindungan terhadap konsumen. Beberapa hal yang dapat dilakukan konsumen untuk melindungi dirinya diantaranya dengan berani menanyakan informasi yang kurang jelas pada barang dan/jasa yang akan dibeli, berani memberikan masukan terhadap produk yang kualitasnya dirasakan kurang sesuai, serta berani menggunakan pengaduan untuk diketahui oleh lembaga, perusahaan atau instansi terkait agar dapat ditindak lanjuti. Menurut Kementerian PPN/ Bappenas (2016) sebanyak 42\% konsumen yang mengalami masalah dalam pembelian dan/atau penggunaan barang/jasa, lebih memilih untuk tidak melakukan pengaduan, dengan alasan utama resiko kerugian tidak besar (37\%); tidak tahu lokasi tempat pengaduan (24\%); beranggapan prosesnya rumit dan lama (20\%). Padahal dalam UUPK sudah dijelaskan hak konsumen untuk mendapatkan informasi yang benar, didengar keluhannya dan mendapatkan kompensasi atas barang/jasa yang tidak sesuai sebagaimana mestinya.

Sebagai konsumen, masyarakat harus cerdas dalam memilih pelbagai produk impor yang beredar. Konsumen cerdas di era MEA

19 Damianus Andreas, BPKN, Badan Perlindungan Konsumen yang Tak Beken,https://tirto.id/bpkn-badanperlindungan-konsumen-yang-tak-beken-cyei (diakses pada 12 Februari 2018).

20 Bappenas, Hari Konsumen Nasional 2016: Momentum Tingkatkan Martabat Konsumen, https://www.bappenas. go.id/id/berita-dan-siaran-pers/hari-konsumen-nasional-2016-momentum-tingkatkan-martabat-konsumen/ (diakses pada 13 Februari 2018). 
diharapkan dapat lebih teliti lagi dalam memilih barang yang akan dikonsumsi.

\section{Penyelesaian Sengketa Konsumen dalam Mendukung Era Masyarakat Ekonomi ASEAN}

Perlindungan konsumen merupakan prasyarat mutlak dalam mewujudkan perekonomian yang sehat melalui keseimbangan antara perlindungan kepentingan konsumen dan pelaku usaha. ${ }^{21}$ Penyelesaian sengketa konsumen, sebagai salah satu bentuk mekanisme perlindungan konsumen, dapat ditempuh melalui pengadilan atau di luar pengadilan berdasarkan pilihan sukarela para pihak yang bersengketa. Penyelesaian sengketa konsumen sebagaimana dimaksud di atas tidak menutup kemungkinan penyelesaian damai oleh para pihak yang bersengketa.

Pengaturan penyelesaian sengketa diatur dalam Pasal 45 Undang-Undang Perlindungan Konsumen sebagai berikut:

a. Setiap konsumen yang dirugikan dapat menggugat pelaku usaha melalui lembaga yang bertugas menyelesaikan sengketa antara konsumen dan pelaku usaha atau melalui peradilan yang berada di lingkungan peradilan umum.

b. Penyelesaian sengketa konsumen dapat ditempuh melalui pengadilan atau di luar pengadilan berdasarkan pilihan sukarela para pihak yang bersengketa.

c. Penyelesaian sengketa di luar pengadilan sebagaimana dimaksud pada ayat (2) tidak menghilangkan tanggung jawab pidana sebagaimana diatur dalam undang-undang. d. Apabila telah dipilih upaya penyelesaian sengketa konsumen di luar pengadilan gugatan melalui pengadilan hanya dapat ditempuh apabila upaya tersebut dinyatakan tidak berhasil oleh salah satu pihak atau oleh para pihak yang bersengketa.

Merujuk pada ketentuan pasal tersebut, maka terdapat beberapa mekanisme penyelesaian sengketa yang dapat ditempuh Konsumen yakni melalui pengadilan dan di luar pengadilan.

\section{a. Penyelesaian Sengketa Konsumen Melalui Pengadilan}

Menurut Pasal 48 UUPK, penyelesaian sengketa konsumen melalui pengadilan mengacu pada ketentuan tentang peradilan umum. Dalam kaitan ini Pasal 46 ayat (1) UUPK menentukan:

1) Gugatan atas pelanggaran pelaku usaha dapat dilakukan oleh:

a. Seorang konsumen yang dirugikan atau ahli waris yang bersangkutan;

b. Kelompok konsumen yang mempunyai kepentingan yang sama;

c. Lembaga perlindungan konsumen swadaya masyarakat yang memenuhi syarat, yaitu berbentuk badan hukum atau yayasan, yang dalam anggaran dasarnya menyebutkan dengan tegas bahwa tujuan didirikannya organisasi tersebut adalah untuk kepentingan perlindungan konsumen dan telah melaksanakan kegiatan sesuai dengan anggaran dasarnya;

21 Direktorat Jenderal Standarisasi dan Perlindungan Konsumen Kementrian Perdagangan, Pilar-Pilar Peningkatan Daya Saing \& Perlindungan Konsumen (Jakarta:2011), hlm. 62 
d. Pemerintah dan/atau instansi terkait apabila barang dan/atau jasa yang dikonsumsi atau dimanfaatkan mengakibatkan kerugian materi yang besar dan/atau korban yang tidak sedikit.

2) Gugatan yang diajukan oleh sekelompok konsumen, lembaga perlindungan konsumen swadaya masyarakat atau pemerintah sebagaimana dimaksud pada ayat (1) huruf b, huruf $c$, atau huruf d diajukan kepada peradilan umum.

3) Ketentuan lebih lanjut mengenai kerugian materi yang besar dan/atau korban yang tidak sedikit sebagaimana dimaksud pada ayat (1) huruf $d$ diatur dengan Peraturan Pemerintah.

\section{b. Penyelesaian Sengketa di Luar Pengadilan}

Penyelesaian sengketa dalam dunia bisnis diharapkan sedapat mungkin tidak merusak hubungan bisnis dan dapat menemukan winwin solution bukan win-lose solution. Sulit ditemukan apabila antar pihak membawa sengketanya ke pengadilan yang pasti akan berakhir dengan kekalahan salah satu pihak dan kemenangan pihak lainnya atau win-lose solution. Atas dasar hal tersebut penyelesaian sengketa di luar pengadilan juga dikenal dalam Undang-Undang Perlindungan Konsumen. ${ }^{22}$

\section{1) Penyelesaian penggantian kerugian seketika (secara langsung) dengan jalan damai}

Menurut Pasal 19 ayat (1) dan (3) UndangUndang Perlindungan Konsumen ini, konsumen yang merasa dirugikan dapat menuntut secara langsung penggantian kerugian kepada produsen dan produsen harus memberi tanggapan dan/atau penyelesaian dalam jangka waktu 7 hari setelah transaksi berlangsung. Mengikuti ketentuan Undang-Undang Nomor 30 Tahun 1999 tentang Arbitrase dan Alternatif Penyelesaian Sengketa, sehubungan penyelesaian sengketa konsumen ini, cara penyelesaian sengketa di luar pengadilan itu dapat berupa konsultasi, negosiasi, mediasi konsiliasi atau penilaian ahli.

Kerugian yang dapat dituntut sesuai dengan Pasal 19 ayat (1) UUPK terdiri atas kerugian karena kerusakan, pencemaran dan kerugian lain akibat dari mengkonsumsi barang dan/atau jasa. Bentuk penggantian kerugiannya dapat berupa;

1) Pengembalian uang seharga pembelian barang dan/atau jasa;

2) Penggantian barang dan/atau jasa sejenis atau setara nilainya; atau

3) Perawatan kesehatan; atau

4) Pemberian santunan yang sesuai

\section{2) Tuntutan penggantian kerugian melalui Badan Penyelesaian Sengketa Konsumen (BPSK)}

Menurut Pasal 1 butir 11 Undang-Undang Nomor 8 Tahun 1999 tentang Perlindungan Konsumen, yang dimaksud dengan Badan Penyelesaian Sengketa Konsumen (BPSK) adalah badan yang bertugas menangani dan menyelesaikan sengketa antara Pelaku Usaha dan Konsumen. Terbentuknya lembaga BPSK memberikan dampak kepada penyelesaian sengketa konsumen yang dapat dilakukan secara cepat, mudah dan murah. Keberadaan

22 Arfian Setiantoro,Perlindungan Hukum Terhadap Konsumen Atas Ketidaksesuaian Harga Dalam Pembayaran Argometer di Taksi, (Semarang: Skripsi,Universitas Diponegoro,2016), Semarang, hlm. 52. 
BPSK juga diharapkan akan mengurangi beban tumpukan perkara di pengadilan. ${ }^{23}$

Permohonan Penyelesaian Sengketa Konsumen dapat diajukan secara lisan atau tertulis ke BPSK melalui Sekretariat BPSK setempat oleh konsumen, yang memuat:

(1) Identitas konsumen, ahli waris atau kuasanya disertai bukti diri

(2) Nama dan alamat pelaku usaha

(3) Barang atau Jasa yang diadukan

(4) Bukti perolehan, keterangan tempat, waktu dan tanggal perolehan barang atau jasa yang diadukan.

(5) Saksi-saksi yang mengetahui perolehan barang atau jasa, foto-foto barang atau kegiatan pelaksanaan jasa, bila ada. (Pasal 16 SK Menperindag Nomor 350/ MPP/ Kep/12/2001).

Persidangan pada Badan Penyelesaian Konsumen dapat ditempuh melalui 3 (tiga) cara, yaitu:

a) Persidangan dengan cara Arbitrase

Arbitrase merupakan cara penyelesaian sengketa perdata yang dilakukan di luar peradilan umum dan didasarkan pada perjanjian arbritase yang dibuat oleh para pihak yang bersengketa.

b) Persidangan dengan cara Konsiliasi

Penyelesaian sengketa dengan konsiliasi memiliki banyak kesamaan dengan arbitrase dimana menyerahkan sengketa kepada pihak kita untuk diberikan pendapatnya kemudian disampaikan kepada para pihak.
Namun pendapat konsiliator tidak mengikat sebagaimana mengikatnya putusan arbitrase. $^{24}$

c) Persidangan dengan cara Mediasi Mediasi adalah proses penyelesaian sengketa dengan perantara pihak ketiga, yakni pihak yang memberi masukan-masukan kepada para pihak untuk menyelesaikan sengketa mereka. Berbeda dengan arbitrase, pada mediasi tidak terdapat kewajiban para pihak untuk mentaati apa yang disarankan oleh mediator. $^{25}$

Isi putusan Majelis Badan Badan Penyelesaian Sengketa Konsumen (BPSK) bersifat final dan mengikat (Pasal 54 ayat (3) Undang-Undang Nomor 8 Tahun 1999 tentang Perlindungan Konsumen jo. Pasal 42 ayat (1) Keputusan Menteri Perindustrian dan Perdagangan RI Nomor 350/Mpp/Kep/12/2001 tentang Pelaksanaan Tugas dan Wewenang Badan Penyelesaian Konsumen). Pasal 56 Ayat (2) UUPK disebutkan bahwa para pihak dapat mengajukan keberatan kepada Pengadilan Negeri paling lambat 14 (empat belas) hari kerja setelah menerima pemberitahuan putusan BPSK.

\section{3) Penyelesaian sengketa melalui Online Dispute Resolution (ODR)}

Online Dispute Resolution (ODR) adalah penyelesaian sengketa dilakukan dengan menggabungkan informasi pengolahan teknologi komputer dengan fasilitas jaringan 
komunikasi internet. ${ }^{26}$ ODR memberikan kemudahan dalam menyelesaikan sengketa yang terjadi, tidak lagi terhalang oleh ruang, batas waktu, biaya murah dan cepat dalam menyelesaikan masalah dibandingkan penyelesaian Alternative Disputes Resolution (ADR) yang sifatnya konvensional. ODR lahir dari sinergisitas antara ADR dan Information of Computer Technology (ICT) sebagai metode atau langkah untuk menyelesaikan sengketa yang timbul dalam proses online yang mana penyelesaian secara tradisional sangat tidak efektif dan tidak memungkinkan. ${ }^{27}$

Kerangka pihak yang bersengketa (dalam ODR) antara lain: Pihak yang bersengketa 1, Pihak yang bersengketa 2, Fasilitator, dan ICT "Information and Computer Technology" Assistance. ODR dalam hal ini, dilihat dari tipetipe penyelesaian sengketa, hanya berkutat pada penyelesaian commercial law (perdagangan) yang itu harus dapat diselesaikan secara damai, yurisdiksinya adalah meliputi kewenangan untuk menangani kasus-kasus hukum dagang yang hasilnya dapat berupa win-win solution ataupun win-lose solution dari proses e-adjudication (Online Arbitration).

Transaksi e-commerce menjadi pendorong munculnya Online Dispute Resolution. ODR dalam hal ini bisa digunakan sebagai mekanisme penyelesaian sengketa, transaksi online. Secara umum, ODR memiliki empat komponen: ${ }^{28}$

a) Sama seperti ADR, kedua belah pihak yang bersengketa harus bersepakat untuk menyelesaikan kasusnya di luar pengadilan. Bedanya adalah menggunakan internet dalam proses penyelesaiannya.

b) Terdapat panduan dari profesional yang mengarahkan para pihak untuk menjalankan proses ADR dengan menggunakan internet.

c) Pengaturan mengenai ADR berlaku pada pelaksanaan penyelesaian melalui internet

d) Software digunakan sebagai alat untuk bertukar informasi di internet. (Meet Online, Access Database, Send Document and Hold Meetings with Voice and Video Conference).

\section{4) Penyelesaian Sengketa konsumen melalui ASEAN Committee on Consumer Protection $(A C C P)^{29}$}

ASEAN Committee on Consumer Protection (ACCP) merupakan suatu bentuk baru kerja sama regional di ASEAN. Pengarahan pelaksanaan inisiatif dan komitmen berdasarkan ASEAN Economic Community (AEC) Blueprint antar pemerintah negara negara di kawasan. ASEAN Committee on Consumer Protection (ACCP)

26 Adel Candra, Penyelesaian Sengketa Transaksi Elektronik Melalui Online Dispute Resolution (ODR) Kaitan Dengan UU Informasi dan Transaksi Elektronik No.11 Tahun 2008, http://digilib.esaunggul.ac.id/public/UEU-Journal3653-adel-chandra.pdf, (diakses pada 14 Februari 2018).

27 Katsh, E Rifkin, Online Disputes Resolution: Resolving Conflicts in Cyberspace, (San Fransisco:Jossey Bass, 2001), hlm 9, Artikel dalam Jurnal Online Gagah Satria Utama, Online Dispute Resolution: a Revolution in Modern Law Practice, https://law.uii.ac.id/wp-content/uploads/2017/04/V-01-No-03-online-dispute-resolution-arevolution-in-modern-law-practice-gagah-satria-utama.pdf (diakses 01 April 2018)

28 Felikas Petrauskas, Egle Kbartiene. Online Dispute Resolution in Consumer Disputes. Jurisprudencia. Mykolas Romeris Universitty. 2011, hlm. 5, Artikel dalam Jurnal Online Gagah Satria Utama, Online Dispute Resolution: a Revolution in Modern Law Practice, https://law.uii.ac.id/wp-content/uploads/2017/04/V-01-No-03-onlinedispute-resolution-a-revolution-in-modern-law-practice-gagah-satria-utama.pdf (diakses pada 01 April 2018).

29 Association of Southeast ASIAN Nations,ASEAN ECONOMIC COMMUNITY BLUEPRINT, (Jakarta: Asean Secretariat Consumer Protection, 2008) http://www.aec.com.mm/download/Consumer\%20Protection.pdf (diakses pada 13 Februari 2018). 
didirikan pada tahun 2008. Maka pendekatan strategis yang sekiranya diperlukan terhadap perlindungan konsumen telah diadopsi oleh ACCP. Pendekatan ini berisi langkahlangkah kebijakan dan tindakan prioritas terperinci dengan jangka waktu tertentu untuk implementasi, termasuk pengembangan notifikasi dan informasi, antara lain:

a. Mekanisme pertukaran pada tahun 2010;

b. Lintas batas mekanisme ganti rugi konsumen pada tahun 2015; dan

c. Roadmap strategis untuk pengembangan kapasitas pada tahun 2010.

ACCP adalah badan sektoral yang baru dibentuk dan akan dihadapkan dengan pekerjaan yang luas dan program-program yang kompleks. Secara khusus, bidang utama yang menjadi perhatian ACCP adalah pembangunan kapasitas kebutuhan di tingkat regional dan nasional harus diidentifikasi, diprioritaskan dan ditangani dalam kawasan ASEAN. ${ }^{30}$

Tugas dan tantangan yang ada dalam ACCP diantaranya adalah bantuan teknis dan keuangan substansial akan diperlukan dalam proses pengembangan dan promosi kebijakan nasional mengenai perlindungan konsumen, pengaturan hukum dan kelembagaan di masingmasing negara pada perlindungan konsumen harus bersinergi. Di era globalisasi dan integrasi regional saat ini, akan ditemukan kompleksitas tambahan dan kesulitan dalam perlindungan konsumen untuk dikelola oleh semua negara anggota di ASEAN. Khususnya dalam meningkatkan volume dan nilai domestik dan perdagangan lintas negara serta kemajuan yang konstan dan cepat dalam teknologi komunikasi, produksi dan perdagangan e-commerce.

Idealnya perlindungan konsumen yang diberikan kepada masyarakat haruslah bersifat preventif, yaitu perlindungan sebelum konsumen mengalami kerugian atau menderita sakit akibat mengkonsumsi barang dan/atau jasa. Kenyataannya, dalam penyelenggaraan perlindungan konsumen di Indonesia saat ini hal tersebut masih jauh dari yang diharapkan. Ini disebabkan oleh berbagai faktor yang saling terkait dan ketergantungan satu sama lain. Implementasi di masyarakat adalah perlindungan konsumen yang masih bersifat represif, yaitu perlindungan ketika konsumen telah mengalami kerugian atau menderita sakit akibat mengkonsumsi barang dan atau jasa. Lembaga yang diharapkan dapat berperan untuk melindungi masyarakat konsumen secara preventif adalah Badan Perlindungan Konsumen Nasional (BPKN) dan Lembaga Perlindungan Konsumen Swadaya Masyarakat (LPKSM), sedangkan lembaga yang berperan secara represif adalah Badan Penyelesaian Sengketa Konsumen (BPSK). ${ }^{31}$

\section{Penutup}

Di era globalisasi, ketika batas-batas suatu negara akan menjadi kabur, di satu pihak terjadi keterkaitan antara ekonomi nasional dengan perekonomian internasional akan semakin erat. Adanya Masyarakat Ekonomi Asean (MEA), membuat masyarakat Indonesia dimudahkan dalam pembelian barang dan jasa. Di sisi lain jangkauan pembelian barang dan jasa melalui transaksi e-commerce berpotensi menimbulkan

Ibid.

31 Direktorat Jenderal Standarisasi dan Perlindungan Konsumen Kementrian Perdagangan, Loc.cit. 
sengketa. Berdasarkan data YLKI tahun 2017, YLKI telah menerima laporan pengaduan 642 aduan, dengan 101 berasal dari belanja online. Konsumen di era MEA diharuskan lebih selektif dalam transaksi jual beli e-commerce. Sejalan dengan hal tersebut, menjadi konsumen cerdas dengan menjalankan hak dan kewajiban konsumen sesuai dengan UUPK di era MEA sangat diperlukan agar membantu mengurangi risiko atau sengketa yang timbul dari transaksi e-commerce. Konsumen cerdas, dituntut selalu mencari alternatif penyelesaian sengketa yang lebih win-win solution.

Perlindungan hukum bagi konsumen untuk menyelesaikan sengketa konsumen yang bersifat represif, yaitu dengan perlindungan ketika konsumen telah mengalami kerugian atau menderita sakit akibat mengkonsumsi barang dan atau jasa. Lembaga yang diharapkan dapat berperan penting untuk melindungi masyarakat/konsumen adalah bukan hanya lembaga peradilan yang bersifat litigasi yang berada pada peradilan umum tapi lembaga nonlitigasi seperti Badan Penyelesaian Sengketa Konsumen (BPSK) dan lembaga arbitrase lainnya. Melalui ODR salah satu alternatif penyelesain sengketa transaksi e-commerce, ODR lahir dari sinergisitas antara Alternative Disputes Resolution (ADR) dan Information of Computer Technology (ICT) sebagai metode atau langkah untuk menyelesaikan sengketa yang timbul dalam proses online yang mana penyelesaian secara litigasi sangat tidak memungkinkan. Jika kasus e-commerce lebih mengarah lintas batas Negara di ASEAN, maka bisa menggunakan ACCP karena sesuai amanat yang dikembangkan dalam roadmap MEA mengenai perlindungan konsumen.

Idealnya perlindungan konsumen yang diberikan kepada masyarakat haruslah bersifat preventif, misalnya adanya sosialisasi kebijakan perlindungan konsumen terhadap konsumen dan pelaku usaha di berbagai daerah sebagai upaya dalam meminimalisir penggunaan barang yang tidak sesuai dengan standar barang yang berlaku masing-masing negara. Pemberian edukasi kepada konsumen melalui klinik konsumen terpadu. Pelatihan motivator perlindungan konsumen di daerah sebagai upaya menumbuh-kembangkan konsumen untuk memiliki sifat kritis, cerdas, dan berhatihati dalam mengkonsumsi atau memanfaatkan barang dan/atau jasa. Serta perlunya sinergisitas antar setiap kebijakan atau peraturan yang dibuat pemerintah agar tidak tumpang tindih dan selalu memberikan keleluasaan adanya penyelesaian sengketa di luar pengadilan.

\section{Daftar Pustaka}

\section{Buku}

Ahmadi Miru dan Sutarman Yodo, Hukum Perlindungan Konsumen, (Jakarta: PT Raja Grafindo,2014).

Jimmy Joses Sembiring, Cara Menyelesaikan Sengketa di Luar Pengadilan: Negosiasi, Mediasi, Konsiliasi, dan Arbitrase, (Jakarta: Visimedia, 2011).

Francis Fukuyama, The End of History and The Last of Man, Kemenangan Kapitalisme dan Demokrasi Liberal, Terjemahan oleh: Amrullah, (Yogyakarta: Qalam,2004).

Janus Sidabalok, Hukum Perlindungan Konsumen Indonesia, (Bandung: PT Citra Aditya Bakti, 2014).

Roni Hanitjo Soemitro, Metodologi Penelitian Hukum dan Jurimetri, (Jakarta: Ghalia Indonesia,1982).

Soerjono Soekanto dan Sri Mamudji, Penelitian Hukum Normatif Suatu Tinjauan Singkat, (Jakarta: PT. Raja Grafindo Persada, 2004).

Susanti Adi Nugroho, Proses Penyelesaian Sengketa Konsumen Ditinjau dari Hukum Acara Serta Kendala Implementasinya, (Jakarta: Prenadamedia Group, 2009)

Zainuddin Ali, Metode Penelitian Hukum, (Jakarta: Sinar Grafika,2010). 


\section{Makalah/Artikel/Laporan/Hasil Penelitian}

Arfian Setiantoro, Perlindungan Hukum Terhadap Konsumen Atas Ketidaksesuaian Harga Dalam Pembayaran Argometer di Taksi, (Semarang: Skripsi, Universitas Diponegoro,2016).

Direktorat Jenderal Standarisasi dan Perlindungan Konsumen Kementrian Perdagangan, PilarPilar Peningkatan Daya Saing \& Perlindungan Konsumen (Jakarta:2011).

\section{Internet}

Abdul Manap Pulungan, Indonesia dan MEA: Bertarung dengan Tangan Kosong, ht t p s:// w w w. cnnindonesia.com / ekonomi/20151231160041-79-101461/ indonesia-dan-mea-bertarung-dengan-tangankosong (diakses pada 13 Februari 2018).

Adel Chandra, Penyelesaian Sengketa Transaksi Elektronik Melalui Online Dispute Resolution (ODR) Kaitan Dengan UU Informasi dan Transaksi Elektronik No. 11 Tahun 2008, http://digilib. esaunggul.ac.id/public/UEU-Journal-3653-adelchandra.pdf, (diakses pada 14 Februari 2018).

Adinda Ade Mustami, Sumbangan Transaksi E-Commerce ke PDB Diperkirakan Hanya 0,75\%, http://nasional.kontan.co.id/news/sumbangantransaksi-e-commerce-ke-pdb-diperkirakanhanya-075 (diakses pada 15 Februari 2018).

Admin PilihKartu.com, E-Wallet Bentuk Lain dari E-Money yang Sebaiknya Kamu Tahu, https:// pilihkartu.com/tips-kartu-kredit/ewalletbentuk-lain-dari-emoney-yang-sebaiknya-kamutahu (diakses pada 01 April 2018).

Agustin Setyo Wardani, Pemerintah Terbitkan Roadmap E-Commerce, Ini 8 Aspek Regulasinya, http://tekno.liputan6.com/read/2648966/ pemerintah-terbitkan-roadmap-e-commerceini-8-aspek-regulasinya (diakses pada 15 Februari 2018).

Association of Southeast ASIAN Nations, ASEAN Economic Community Blueprint, (Jakarta: Asean Secretariat Consumer Protection, 2008) http:// www.aec.com.mm/download/Consumer\%20 Protection.pdf (diakses pada 13 Februari 2018).

Bappenas, Hari Konsumen Nasional 2016: Momentum Tingkatkan Martabat Konsumen, https://www.bappenas.go.id/id/berita-dansiaran-pers/hari-konsumen-nasional-2016momentum-tingkatkan-martabat-konsumen/ (diakses pada 13 Februari 2018).
Damianus Andreas, BPKN, Badan Perlindungan Konsumen yang Tak Beken, https://tirto.id/ bpkn-badan-perlindungan-konsumen-yang-takbeken-cyei (diakses pada 12 Februari 2018).

Farizal F. Kamal, Cyber Business, cet. 3. (Jakarta: Elex Media Komputindo, 1999), Artikel dalam Jurnal Online Tetanoe Bernada, Upaya Perlindungan Hukum Pada Konsumen Dalam Transaksi E-commerce Untuk Mendukung Pertumbuhan Ekonomi Digital Di Indonesia,https://www.researchgate. net/publication/317562107_UPAYA_ PERLINDUNGAN_HUKUM_PADA_KONSUMEN_ DALAM_TRANSAKSI_ECOMMERCE_UNTUK_ MENDUKUNG_PERTUMBUHAN_EKONOMI_ DIGITAL_DI_INDONESIA_LEGAL_PROTECTION_ FOR_ECOMMERCE_TRANSACTION'S CONSUMERS_TO_SUPPORT_THE_DIGITAL (diakses pada 01 April 2018).

Felikas Petrauskas, Egle Kbartiene. Online Dispute Resolution in Consumer Disputes. (Jurisprudencia: Mykolas Romeris Universitty, 2011), Artikel dalam Jurnal Online Gagah Satria Utama, Online Dispute Resolution: a Revolution in Modern Law Practice, https://law.uii.ac.id/wpcontent/uploads/2017/04/V-01-No-03-onlinedispute-resolution-a-revolution-in-modern-lawpractice-gagah-satria-utama.pdf (diakses pada 01 April 2018).

Katsh, E Rifkin, Online Disputes Resolution: Resolving Conflicts in Cyberspace (San Fransisco: Jossey Bass, 2001), Artikel dalam Jurnal Online Gagah Satria Utama, Online Dispute Resolution: a Revolution in Modern Law Practice, https://law. uii.ac.id/wp-content/uploads/2017/04/V-01No-03-online-dispute-resolution-a-revolutionin-modern-law-practice-gagah-satria-utama.pdf (diakses pada 01 April 2018).

Mansur, D. M. A., Dan E. Gultom, Cyber Law: Aspek Hukum Teknologi Informasi, (Bandung: Refika Aditama, 2005), Artikel dalam Jurnal online: Urgensi Regulasi Komprehensif E-Commerce di Indonesia dalam Menghadapi Masyarakat Ekonomi ASEAN (MEA), http://ojs.uma.ac.id/ index.php/mercatoria/article/view/648, (diakses pada 11 Februari 2018).

Mohammad Ikbal, Aspek Hukum Perlindungan Konsumen dalam Transaksi Elektronik (E-Commerce) Menghadapi Masyarakat Ekonomi ASEAN 2015, https://ojs.uniska-bjm. ac.id/index.php/aldli/article/view/223 (diakses pada 11 Februari 2018). 
Philip F. E. Adipraja, Sri A.K. Dewi, \& Lia Farokhah Sekolah, Analisis Efektifitas dan Keamanan E-Commerce di Indonesia dalam Menghadapi MEA, Tinggi Manajeman Informatika \& Komputer Perguruan Tinggi ASIA, (Malang: Mantri, 2007),https://www. researchgate.net/profile/Philip_Adipraja/ publication/303699038_ANALISIS EFEKTIFITAS_DAN_KEAMANAN_ECOMMERCE_ DI_INDONESIA_DALAM_MENGHADAPI_MEA/ links/5982c8b8458515a60df81139/ANALISISEFEKTIFITAS-DAN-KEAMANAN-ECOMMERCEDI-INDONESIA-DALAM-MENGHADAPI-MEA.pdf (diakses pada 11 Februari 2018).
Pramdia Arhando Julianto, YLKI: Meski Dirugikan, Konsumen Indonesia Takut Melapor, https://ekonomi.kompas.com/ $\mathrm{read} / 2018 / 01 / 19 / 153100426 /$ ylki--meskidirugikan-konsumen-indonesia-takut-melapor (diakses pada 01 April 2018).

Risky Maulana, Tren Perilaku Konsumen Belanja Online Indonesia Tahun 2018 Menurut iPrice, https://id.techinasia.com/tren-perilakukonsumen-online-indonesia-menurut-iprice (diakses pada 13 Februari 2018). 